\title{
Neutrophil-to-Lymphocyte Ratio Predicts Coronary Collateral Circulation in Multivessel Coronary Artery Disease
}

\author{
Yasmine F. Siregar*, Zulfikri Mukhtar, Ali N. Nasution, Harris Hasan, Abdullah A. Siregar, Cut A. Andra \\ Department of Cardiology and Vascular Medicine, Faculty of Medicine, Universitas Sumatera Utara, Haji Adam Malik General \\ Hospital Medan, North Sumatera, Indonesia
}

\section{$\underline{\text { ARTICLE INFO }}$}

*Corresponding author

Email:

yasminefitrina@gmail.com

Address:

Department of Cardiology and

Vascular Medicine, Faculty of Medicine, Universitas Sumatera Utara

Haji Adam Malik Hospital,

Jalan Bunga Lau, Medan, North Sumatera,

Indonesia

Keywords:

coronary collateral circulation;

neutrophil to lymphocyte ratio;

coronary artery disease;

hematologic parameter

Manuscript submitted: February 19, 2019

Revised and accepted: June 20, 2019

\begin{abstract}
Background: Coronary collateral circulation (CCC) is an adaptive response to chronic myocardial ischemia. Patients with coronary stenosis develop varying degrees of collateral. Levels of inflammatory cells were suggested as potential determinants of collateral development. Neutrophil to lymphocyte (N/L) ratio has been proposed as a prognostic marker to determine systemic inflammatory response and the development of CCC. Our aim was to determine the relationship between N/L ratio and development of CCC in patients with coronary artery disease (CAD) with multivessel disease.
\end{abstract}

Method:A total of 151 patients with multivessel disease were included in this study. Coronary collateral grades were classified according to Rentrop collateral grades as either poorly developed CCC (Rentrop grade $0-1$ ) or well developed CCC (Rentrop grades 2-3). Factors significant at the $p \leq 0.25$ in the bivariate models were put into multiple logistic regressions. The receiveroperating characteristic (ROC) analysis were performed to determine the cutoff value of NLR in predicting poor CCC.

Result: Of the 151 CAD patients in this study, 76 patients had poorly developed CCC and 75 patients had well developed CCC. Poorly developed CCC had significantly higher N/L ratio than well developed CCC $(2.25 \pm 1.189$ vs. $3.03 \pm 1.527, \mathrm{p}<0.001$ ). Logistic regression analysis showed that $\mathrm{N} / \mathrm{L}$ ratio $(\mathrm{OR}$ 0.756 ; CI $95 \% 0.587-0.974$, p 0.031 ) was independent predictor of poorly developed CCC. The ROC analysis provided a cut-off value of 1.99 (AUC 0.72, sensitivity $78.9 \%$, specificity $52 \%$ ) for N/L ratio to predict poorly developed CCC.

Conclusion: Higher neutrophil to lymphocyte ratio was useful in predicting poor coronary collateral circulation in stable coronary heart disease with multivessel disease. Neutrophil to lymphocyte ratio $>1.99$ was independently associated with impairment in coronary collateralization. This value had a sensitivity of $78.9 \%$ and specificity of $52 \%$.

\section{INTISARI}

Latar Belakang: Kolateral arteri koroner (KAK) merupakan respon adaptif terhadap iskemia miokard kronis. Pasien dengan stenosis koroner memiliki derajat kolateral yang bervariasi. Kadar sel inflamasi adalah determinan dari perkembangan pembuluh kolateral. Rasio neutrofil-limfosit (RNL) berperan sebagai penanda prognostik respon inflamasi sistemik dan perkembangan KAK. Penelitan ini bertujuan untuk melihat hubungan antara nilai RNL dengan perkembangan KAK pada pasien penyakit jantung koroner (PJK) dengan multivessel disease.

Metode: Sebanyak 151 penderita multivessel disease terlibat dalam penelitian ini. Derajat KAK diklasifikasikan menurut klasifikasi Rentrop, yaitu kurang 
baik (nilai Rentrop 0-1) dan baik (nilai Rentrop 2-3). Faktor-faktor yang signifikan dengan nilai $\mathrm{p} \leq 0,25$ pada model bivariat akan dimasukkan kedalam regresi logistik multipel. Analisisreceiver-operating characteristic (ROC) dilakukan untuk menentukan titik potong nilai RNL yang memprediksi kondisi KAK yang kurang baik.

Hasil: Dari 151 pasien PJK dalam studi ini, dijumpai76 penderita dengan KAK kurang baik dan 75 penderita dengan KAK baik. Penderita PJK dengan KAK yang kurang baik memiliki nilai RNL yang lebih tinggi dibandingkan penderita PJK dengan KAK baik $(2,25 \pm 1,189$ vs. $3,03 \pm 1,527, p<0,001)$ Hasil analisis regresi logistik multipel mendapatkan nilai RNL yang tinggi adalah prediktor independen KAK yang kurang baik (OR 0,756; IK 95\% 0,587 - 0,974). Hasil analisis ROC menemukan nilai potong RNL 1,99 (AUC 0,72, sensitivitas 78,9\%, spesifisitas 52\%) untuk memprediksi KAK yang kurang baik.

Kesimpulan: Rasion eutrofil-limfosit yang tinggi mampu memprediksi keadaan kolateral arteri koroner yang kurang baik pada penderita penyakit jantung koroner stabil

\section{Introduction}

Stable coronary artery disease (SCAD) is caused by formation of atheromatous plaque in the coronary arteries which causes obstruction and slowly narrow one or more epicardial coronary arteries.1,2 This causes an imbalance between myocardial oxygen supply and demand which could produce myocardial ischemia and accumulation of residual metabolites. Outcome of SCAD depends on the area of infarction. A reduction in area of infarction reduces cardiovascular mortality. The extent of infarction is influenced by several factors, such as myocardial oxygen consumption, duration of occlusion, area at risk for ischemia, and supply of collateral coronary arteries to the area of ischemia. ${ }^{3}$

Coronary collateral circulation (CCC) has been known as a source of alternative blood supply to myocardial areas at risk of infarction. ${ }^{4}$ CCC arises from small anastomosis that are directly related to large coronary arteries and acts as precursors of collateral circulation to maintain myocardial perfusion in severe stenosis proximal to coronary arteries. ${ }^{5}$ Well-developed collateral coronary arteries reduce ischemia, infarct area, left ventricular dysfunction, and provide better outcomes. 6,7

Angiogenesis (formation of new blood vessels) and arteriogenesis (growth of existing arterioles) is the basis of the development of CCC. Several studies have shown that there are several other factors that influence the formation of CCC, such as severity/progression of coronary artery stenosis, diabetes mellitus, hypertension, smoking, endothelial dysfunction, exercise, endogenous mediators, oxidative stress and certain drugs. ${ }^{4}$ During the development of CCC, many endogenous factors are involved, such as growth factors, nitric oxide, inflammatory and neurohormonal signs that cause endothelial dysfunction. ${ }^{8}$

There is a complex relationship between new blood vessel formation and inflammatory process. Several studies reported a systemic inflammatory response associated with the presence of systemic atherosclerosis and the development of coronary collateral circulation. Leukocyte, a marker of acute and chronic inflammation, have become the focus of research over the past two decades. Leukocyte is not only a risk factor but also acts as prognostic factor for cardiovascular disease.9,10,11 Leukocyte levels and their subtypes (neutrophils, monocytes and lymphocytes) are associated with short-term and long-term mortality, severe atherosclerosis and low response to fibrinolytic therapy in patients with acute myocardial infarction. ${ }^{12}$

Neutrophils are the first inflammatory response towards injured myocardium and play a role in thrombosis and inflammation. At the time of ischemia, neutrophils gather in the ischaemic areas and release proteolytic enzymes or Reactive Oxygen Species (ROS), causing microvascular occlusion and damaging the surrounding myocytes.11,13,14 Meanwhile, lymphocytes play a role in specific immune responses. ${ }^{15}$ Lymphopenia in inflammatory process is associated with an increase in steroid levels (cortisol) due to stress and an increased incidence of apoptosis. ${ }^{16}$ Mor et al. reported lymphopenia associated with instability of atherosclerotic plaques in the acute phase of acute coronary syndrome. This decrease in lymphocyte numbers is a marker of poor outcome in the acute process. ${ }^{17}$

The N/L ratio shows an imbalance between the combination of inflammatory markers, namely neutrophils as an active component of inflammation with lymphocytes as a regulatory and protective component. Kalkan reported that higher N/L ratio value predicts poor development of CCC in chronic total obstruction. ${ }^{18}$ Indirectly the N/L ratio had the ability to detect high risk patients. ${ }^{19}$

\section{Method}

\section{Population and Design}

This cross sectional study included 151 consecutive patients with stable CAD with multivessel disease admitted 
to Adam Malik General Hospital in Medan, Indonesia from January 2018 until December 2018. Inclusion criteria were patients who signed consent for coronary angiography, had significant stenosis in more than one vessel, had no history of PCI or CABG, had no history of valvular heart disease and congenital heart disease, and had no evidence of infection, hematologic disease, antibiotic use, immunosuppresant and cancer. Exclusion criteria was poor coronary angiography view.

Patient's data such as profile, risk factors, therapy during hospitalization, laboratory results, and coronary angiography results were obtained from medical record. Inflammatory markers included were leukocyte, neutrophils, lymphocyte, monocyte (both relative and absolute) and N/L ratio. The angiographic characteristics, which included number of diseased coronary artery and location of coronary lesion, were obtained from reviewing the angiogram. Two interventional cardiologists blinded to the study protocol analyzed the angiographic results. The coronary collateral circulation was graded using the Rentrop classification: grade $0=$ no filling of any collateral vessel; grade $1=$ filling of side branches of the artery to the epicardial segment; grade $2=$ partial filling of the epicardial artery by collateral vessels; and grade $3=$ complete filling of the epicardial artery by a collateral vessel. ${ }^{20}$ Patients were divided into 2 groups according to the grade of coronary collateral circulation. The 'poor collateral group' consisted of patients with grade- 0 or grade- 1 collaterals. The 'good collateral group' consisted of patients with grade- 2 or grade- 3 collaterals. In patients with more than 1 collateral vessel filling the occluded vessel, the collateral vessel with the highest Rentrop grade was used for analysis.

\section{Statistical Analysis}

All statistical analyses were carried out using the SPSS statistical software, version 20 . The data were presented as mean \pm SD or median and interquartile range for continuous variables. Categorical variables was presented as percentage. The normality test for continuous variables in all study subjects used one sample Kolmogorov Smirnov $(n>50)$. In continuous variables compared with two free samples T test (Two Samples Independent Student's t-test) on normal distributed data or Mann Whitney U Test if the data was not normally distributed. In categorical variables, an analytical test was performed using chi squared or fisher exact tests. Data with p value $<0.25$ would be included in multivariate analysis to identify the factors that were independently associated with the grade of coronary collateral circulation. A receiver-operating characteristic (ROC) curve was constructed. Multivariate analysis was performed using logistic regression. The $p$ value $<0.05$ was considered as statistically significant.

\section{Results}

A total of 151 patients with chronic stable angina pectoris were enrolled. The mean age was $56.73 \pm 7$ years and $77.5 \%$ of the patients were male. Among 75 patients with good coronary collateral circulation, 18 patients have Rentrop grades 3 and 57 patients have Rentrop grades 2 . Among 76 patients with poor coronary collateral circulation, 72 patients have Rentrop grades 1 and 4 patients have no coronary collaterals. Demographic and clinical patient characteristics were listed in Table 1 . A total of 101 subjects (66.9\%) have hypertension, 37 subjects (24.5\%) have diabetes mellitus, 35 subjects (23.2\%) have dyslipidemia and 102 subjects $(67.5 \%)$ have a history of smoking. Based on body mass index, the majority of the study subjects were overweight (47\%), followed by normoweight $(44.4 \%)$, obese $(7.3 \%)$ and underweight (1.3\%). Demographic, clinical patient characteristics and therapy were listed in Table 1. Gender, age, risk factor and body mass index were not significantly different between the good CCC and poor CCC groups. Dual antiplatelet and statin were received by $99.3 \%$ and $94 \%$ of subjects, respectively. There were also no difference in antiplatelet, beta blocker, nitrate, CCB, ACEi, ARB, diuretics, MRA dan statin use between both groups.

Laboratory results were listed in Table 2 and Table 3. Laboratory results showed median leukocyte count was 8,890 cell $/ \mu \mathrm{L}$, median neutrophil count was $4.99 \times 10^{3} / \mu \mathrm{L}$, median lymphocyte count was $2.24 \times 10^{3} / \mu \mathrm{L}$, and median monocyte count was $0.69 \times 10^{3} / \mu \mathrm{L}$. Median N/L ratio was 2.38. We found neutrophil count $(5.09 \pm 1.699$ vs $5.51 \pm 1.725$, p 0.033$)$, lymphocyte count $(2.56 \pm 0.979$ vs $2.03 \pm 0.702$, p <0.001), relative lymphocyte count $(26.69 \pm 10.903$ vs $23.53 \pm 10.186$, p 0.012$)$ and median N/L ratio $(2.25 \pm 1.189$ vs $3.03 \pm 1.527, \mathrm{p}<0.001)$ were statistically different between the good CCC and poor CCC groups.

Coronary angiography characteristics were listed in Table 4 and 5. Coronary angiography presented 3-vessel disease in $47.7 \%$ subjects and coronary lesion mostly involved proximal LAD. Severity of CAD based on number of diseased coronary artery were not significantly different between both groups.

By multiple logistic regression analyses, risk factors associated with the development of poor CCC at the $\mathrm{p}<0.05$ level including N/L ratio (OR 0.756; 95\% CI 0.587-0.974; $\mathrm{p}$ 0.031), lymphocyte (OR 4.9; 95\% CI 2.541-9.479; $<<0.001$ ), and dyslipidemia (OR 0.325; 95\% CI 0.118-0.892; p 0.029) (Table 6). The ROC analysis provided a cut-off value of 1.99 for N/L ratio to predict poor CCC with 78.9\% sensitivity and $53 \%$ specificity, with the area under the ROC curve being 0.702 (95\% CI $0.619-0.785, \mathrm{p}<0.001$ ) (Figure 1). 
Table 1

Baseline characteristics

\begin{tabular}{|c|c|c|c|c|}
\hline \multirow[b]{2}{*}{ Characteristics } & \multirow[b]{2}{*}{$\mathrm{n}=151$} & \multicolumn{2}{|l|}{ Rentrop } & \multirow[b]{2}{*}{$\mathrm{p}$ value } \\
\hline & & $\begin{array}{l}\text { Good collateral } \\
(\mathrm{n}=75)\end{array}$ & Poor collateral $(n=76)$ & \\
\hline \multicolumn{5}{|l|}{ Gender, n(\%) } \\
\hline Male & $117(77.5 \%)$ & $61(81.3 \%)$ & $56(73.7 \%)$ & 0.261 \\
\hline Female & $34(22.5 \%)$ & $14(18.7 \%)$ & $20(26.3 \%)$ & \\
\hline Age (year) & $56.73 \pm 7.148$ & $56.88 \pm 7.157$ & $56.57 \pm 7.183$ & 0.792 \\
\hline \multicolumn{5}{|l|}{ Risk factor, n (\%) } \\
\hline Hypertension & $101(66.9 \%)$ & $60(66.7 \%)$ & $51(67.1 \%)$ & 0.954 \\
\hline Diabetes Melitus & $37(24.5 \%)$ & $16(21.3 \%)$ & $21(27.6 \%)$ & 0.368 \\
\hline Dyslipidemia & $35(23.2 \%)$ & $13(17.3 \%)$ & $22(28.9 \%)$ & 0.091 \\
\hline Smoking & $102(67.5 \%)$ & $53(70.7 \%)$ & $49(64.5 \%)$ & 0.416 \\
\hline \multicolumn{5}{|c|}{ Body Mass Index, $\mathrm{n}(\%)$} \\
\hline Underweight & $2(1.3 \%)$ & $1(1.3 \%)$ & $1(1.3 \%)$ & 0.753 \\
\hline Normoweight & $67(44.4 \%)$ & $31(41.3 \%)$ & $36(47.4 \%)$ & \\
\hline Overweight & $71(47.0 \%)$ & $36(48.0 \%)$ & $35(46.1 \%)$ & \\
\hline Obese & $11(7.3 \%)$ & $7(9.3 \%)$ & $4(5.3 \%)$ & \\
\hline \multicolumn{5}{|c|}{ Therapy during hospitalization, $\mathrm{n} \%$} \\
\hline Antiplatelet & $150(99.3 \%)$ & 75 (100.0\%) & 75 (98.7\%) & 0.319 \\
\hline Beta Blocker & $132(87.4 \%)$ & $65(86.7 \%)$ & $67(88.2 \%)$ & 0.536 \\
\hline Nitrate & $136(90.1 \%)$ & $66(88.0 \%)$ & $70(92.1 \%)$ & 0.399 \\
\hline СCB & $26(17.2 \%)$ & $13(17.3 \%)$ & $13(17.1 \%)$ & 0.970 \\
\hline ACEi & $74(49.0 \%)$ & $39(52.0 \%)$ & $35(46.1 \%)$ & 0.465 \\
\hline ARB & $50(33.1 \%)$ & $26(34.7 \%)$ & $24(31.6 \%)$ & 0.687 \\
\hline Diuretic & $36(23.6 \%)$ & $19(25.3 \%)$ & $17(22.4 \%)$ & 0.669 \\
\hline MRA & $20(13.2 \%)$ & $10(13.3 \%)$ & $10(13.2 \%)$ & 0.975 \\
\hline Statin & $142(94.0 \%)$ & $69(92.0 \%)$ & $73(96.1 \%)$ & 0.293 \\
\hline
\end{tabular}

*: significant if $\mathrm{p}$ value $<0.05$

Table 2

Association Between Complete Blood Count and Neutrophil to Lymphocyte Ratio with Coronary Collateral Circulation

\begin{tabular}{|c|c|c|c|c|}
\hline \multirow[b]{2}{*}{ Characteristics } & \multirow[b]{2}{*}{$n=151$} & \multicolumn{2}{|l|}{ Rentrop } & \multirow[b]{2}{*}{$\mathrm{p}$ value } \\
\hline & & $\begin{array}{l}\text { Good collateral } \\
(n=75)\end{array}$ & Poor collateral $(n=76)$ & \\
\hline Hemoglobin (g/dl) & $14.00(8.80-17.30)$ & $13.90 \pm 1.599$ & $13.70 \pm 1.850$ & 0.479 \\
\hline Leukocyte $($ cell $/ \mu \mathrm{L})$ & $8,890(3,420-11,780)$ & $10,218 \pm 12.789$ & $9.110 \pm 2.143$ & 0.208 \\
\hline Platelet $($ cell $/ \mu \mathrm{L})$ & $270,152 \pm 68,248$ & $262,373 \pm 62,651$ & $277,828 \pm 72,956$ & 0.165 \\
\hline Neutrophil $\left(10^{3} / \mu \mathrm{L}\right)$ & $4.99(1.02-10.16)$ & $5.09 \pm 1.699$ & $5.51 \pm 1.725$ & $0.033^{*}$ \\
\hline Lymphocyte $\left(10^{3} / \mu \mathrm{L}\right)$ & $2.24(0.63-5.83)$ & $2.56 \pm 0.979$ & $2.03 \pm 0.702$ & $<0.001^{*}$ \\
\hline Monocyte $\left(10^{3} / \mu \mathrm{L}\right)$ & $0.69(0.22-3.76)$ & $0.74 \pm 0.402$ & $0.72 \pm 0.233$ & 0.790 \\
\hline Relative Neutrophil \% & $57.6(16.3-86.20)$ & $52.23 \pm 18.02$ & $56.24 \pm 18.00$ & 0.161 \\
\hline Relative Lymphocyte \% & $25.4(11.5-51.40)$ & $26.69 \pm 10.903$ & $23.53 \pm 10.186$ & $0.012^{*}$ \\
\hline Relative Monocyte \% & $7.70(3.2-17.70)$ & $7.23 \pm 3.162$ & $7.59 \pm 3.279$ & 0.739 \\
\hline RDW \% & $13.0(11.0-17.60)$ & $13.19 \pm 1.153$ & $13.50 \pm 1.386$ & 0.137 \\
\hline Neutropil-lymphocyte ratio (RNL) & $2.38(0.12-8.13)$ & $2.25 \pm 1.189$ & $3.03 \pm 1.527$ & $<0.001^{*}$ \\
\hline
\end{tabular}

$*$ : significant if $\mathrm{p}$ value $<0.05$

Table 3

Association Between Creatinine, Fasting Blood Glucose and Lipid Profile with Coronary Collateral Circulation

\begin{tabular}{|c|c|c|c|c|}
\hline \multirow[b]{2}{*}{ Characteristics } & \multirow[b]{2}{*}{$\mathrm{n}=151$} & \multicolumn{2}{|l|}{ Rentrop } & \multirow[b]{2}{*}{$\mathrm{p}$ value } \\
\hline & & $\begin{array}{l}\text { Good collateral } \\
(n=75)\end{array}$ & Poor collateral $(n=76)$ & \\
\hline Creatinine (mg/dl) & $0.94(0.28-141.0)$ & $1.02 \pm 0.494$ & $3.04 \pm 16.059$ & 0.511 \\
\hline Cholesterol (mg/dl) & $173.0(108.0-330.0)$ & $177.499 \pm 41.430$ & $180.605 \pm 43.506$ & 0.632 \\
\hline Triglyceride (mg/dl) & $117.0(29.0-945.0)$ & $139.81 \pm 78.603$ & $137.38 \pm 113.341$ & 0.489 \\
\hline $\mathrm{HDL}(\mathrm{mg} / \mathrm{dl})$ & $39.0(10.0-124.0)$ & $42.05 \pm 15.664$ & $40.75 \pm 19.485$ & 0.184 \\
\hline
\end{tabular}

\footnotetext{
*: significant if $\mathrm{p}$ value $<0.05$
} 
Table 4

Coronary angiography characteristics

\begin{tabular}{lllll}
\hline Characteristics & LM & LAD & LCX & RCA \\
\hline Lesion (n \%) & $52(34.4 \%)$ & $144(95.4 \%)$ & $133(88.1 \%)$ & $123(81.5 \%)$ \\
Yes & $99(65.6 \%)$ & $7(4.6 \%)$ & $18(11.9 \%)$ & $28(18.5 \%)$ \\
No & & & & \\
Location of lesion & $5(3.3 \%)$ & $10(6.6 \%)$ & $6(4.0 \%)$ & $2(1.3 \%)$ \\
Osteal & $5(3.3 \%)$ & $87(57.6 \%)$ & $63(41.7 \%)$ & $39(25.8 \%)$ \\
Proximal & $9(6.0 \%)$ & $14(9.3 \%)$ & $0(0 \%)$ & $15(9.9 \%)$ \\
Mid & $33(21.9 \%)$ & $0(0 \%)$ & $42(27.8 \%)$ & $33(21.9 \%)$ \\
Distal & $0(0 \%)$ & $33(21.9 \%)$ & $22(14.6 \%)$ & $34(22.5 \%)$ \\
Multiple & $99(65.6 \%)$ & $7(4.6 \%)$ & $18(11.9 \%)$ & $28(18.5 \%)$ \\
Normal &
\end{tabular}

Table 5

Association between coronary angiography and coronary collateral circulation

\begin{tabular}{|c|c|c|c|c|}
\hline \multirow[b]{2}{*}{ Characteristics } & \multirow[b]{2}{*}{$\mathrm{n}=151$} & \multicolumn{2}{|l|}{ Rentrop } & \multirow[t]{2}{*}{ pvalue } \\
\hline & & $\begin{array}{l}\text { Good collateral } \\
(n=75)\end{array}$ & Poor collateral $(n=76)$ & \\
\hline \multicolumn{5}{|c|}{ No of diseased vessel, n(\%) } \\
\hline 2VD & $32(21.2 \%)$ & $10(13.3 \%)$ & $22(28.9 \%)$ & 0.077 \\
\hline 3VD & $72(47.7 \%)$ & $39(52.0 \%)$ & $33(43.4 \%)$ & \\
\hline $1 \mathrm{VD}+\mathrm{LM}$ & $6(4.0 \%)$ & $5(6.7 \%)$ & $1(1.3 \%)$ & \\
\hline 2VD+LM & $8(5.3 \%)$ & $3(4.0 \%)$ & $5(6.6 \%)$ & \\
\hline 3VD+LM & $33(21.9 \%)$ & $18(24.0 \%)$ & $15(19.7 \%)$ & \\
\hline \multicolumn{5}{|c|}{ Coronary artery involved, $\mathrm{n}(\%)$} \\
\hline LM & $52(34.4 \%)$ & $29(38.7 \%)$ & $23(30.3 \%)$ & 0.277 \\
\hline LAD & $144(95.4 \%)$ & $71(94.7 \%)$ & $73(96.1 \%)$ & 0.685 \\
\hline LCX & $133(88.1 \%)$ & $68(90.7 \%)$ & $65(85.5 \%)$ & 0.330 \\
\hline RCA & $123(81.5 \%)$ & $64(85.3 \%)$ & $59(77.6 \%)$ & 0.223 \\
\hline
\end{tabular}

*: significant if $\mathrm{p}$ value $<0.05$

Table 6

\begin{tabular}{llllll}
\multicolumn{6}{l}{ Multivariate Analyses of Poorly Developed Coronary Collateral Circulation } \\
\hline Variable & $\mathrm{B}$ & Wald & $\mathrm{p}$ & OR & 95\% CI \\
\hline N/L ratio & -0.280 & 4.665 & $0.031^{*}$ & 0.756 & $0.587-0.974$ \\
Lymphocyte & 1.591 & 22.426 & $<0001^{*}$ & 4.907 & $2.541-9.479$ \\
Dyslipidaemia & -1.125 & 4.758 & $0.029^{*}$ & 0.325 & $0.118-0.892$ \\
HDL & - & - & - & - & - \\
Coronary Angiography (vs 2VD) & & & & & \\
3VD & 0.841 & 2.073 & 0.150 & 2.319 & $0.738-7.290$ \\
1VD+LM & 3.659 & 6.686 & 0.110 & 38.825 & $2.424-621.786$ \\
2VD+LM & 0.126 & 0.017 & 0.897 & 1.134 & $0.169-7.633$ \\
3VD+LM & 1.082 & 2.400 & 0.121 & 2.950 & $0.751-11.590$ \\
\hline
\end{tabular}

*: significant if $\mathrm{p}$ value $<0.05$

\section{Discussion}

This study was conducted in RSUP $\mathrm{H}$ Adam Malik by collecting samples through medical records of SCAD patients who underwent coronary angiography from January 2018 to December 2018. Of the 151 CAD patients who underwent coronary angiography, $77.5 \%$ were male with a median age of 56 years. There were no difference in age between both groups. Studies in Turkey found that men ranked first in stable CAD patients (76\%) with an average age of more than 62 years. This study found no age difference between both groups (63 \pm 11 vs $61 \pm 11$; p 0.22). ${ }^{21}$ Therefore, it appeared that Asian CAD patients were on average younger than their European counterpart.
This can be attributed to the number of risk factors for coronary heart disease that are more prevalent in Asian than Caucasians, such as smoking and the prevalence of diabetes, which is 2.5 times greater in Caucasians. ${ }^{22}$ The highest risk factors for CAD were smoking (67.5\%) and hypertension (66.9\%). Comparison of risk factors for smoking and hypertension between the two collateral groups did not revealed significant difference. Previous study showed smokers had poorer collateral and no significant difference was found in other risk factors. Koerselman reported that being an active smoker was associated with the better coronary collateral, but pack 
years of smoking was associated with poor collateral circulation. 23

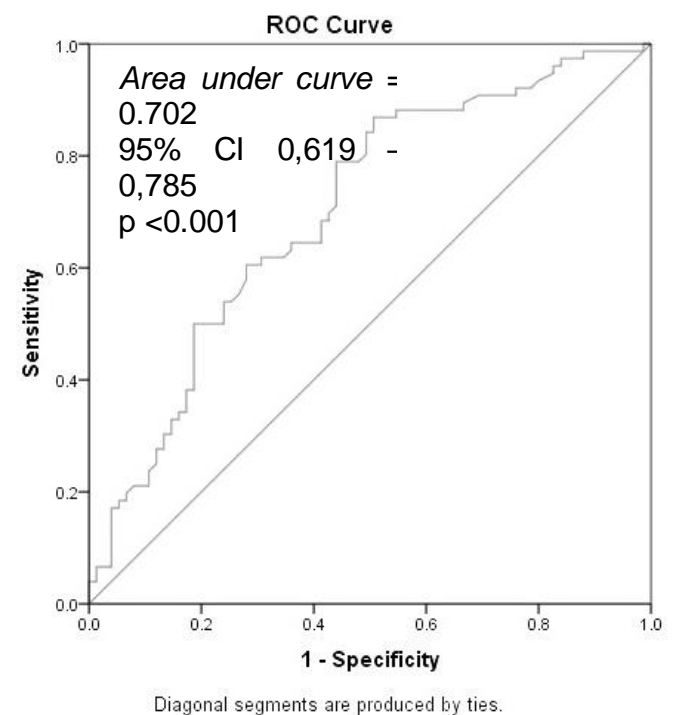

Figure 1. Receiver-operating characteristic curve analysis for neutrophil-to-lymphocyte ratio for prediction of poor collateral

Laboratory tests showed no significant differences in hemoglobin, leukocytes, platelets, monocytes, relative neutrophils, relative monocytes, RDW, creatinine, fasting blood glucose and lipid profile between the two groups. Multivariate analysis showed dyslipidemia predicted poor CCC. Previous study by Kadi found low HDL and high triglyceride were associated with poor CCC $(\mathrm{p}<0.001$ and $\mathrm{p}$ 0.015). ${ }^{24} \mathrm{HDL}$ had antiatherogenic properties, protected against endothelium, and increased the number and function of progenitor cells that play a role in the process of endothelial repair. $24,25,26$

There was no difference between severity of coronary lesions and collateral state ( $p$ 0.077). The degree of collateral varies among patients, and ischeamia was known as a stimulus for collateral development. However, no studies have been able to prove the causative role of ischemia in collateral induction. Clinical studies explained several clinical and angiographic variables related to the degree of collateral circulation. Coronary stenosis severity (stenosis diameter $\geq 75 \%$, $p<0.0001$ ), duration of angina ( $\geq 3$ months, $p<0.0001$ ), proximal lesions ( $p$ 0.02) and duration of coronary occlusion affect the development of collateral coronary arteries. ${ }^{27,28,29,30}$

Epidemiological studies emphasize that chronic mild inflammation is often found in conditions such as diabetes mellitus, hypertension, metabolic syndrome, obesity, smoking, and other bad habits. $31,32,33,34,35,36,37$ Previous studies confirmed a relationship between inflammatory indicators and development of CCC, both in multivessel disease or total coronary occlusion. Increased inflammatory markers, leukocytes and neutrophils were associated with severity of CAD and the grades of coronary collateral circulation. $38,39,40$ Higher leukocyte correlated with poor coronary collateral. ${ }^{41}$ Seiler found that TNF- $\alpha$ was more frequently detected in patients with collaterals that were inadequate compared to adequate collateral. 42 Gulec found that high CRP levels are associated with collateral coronary arteries that are poor especially in patients who have myocardial infarction. ${ }^{43}$

Although inflammatory markers such as neutrophils, eosinophils, and monocytes have been associated with CAD events, N/L ratio is a combination of two inflammatory components. ${ }^{44}$ Higher N/L ratio was correlated with poorer coronary collateral circulation. ${ }^{18}$ Previous study had found that statin administration had beneficial effect on collateral growth. But this study did not find any significant relationship between administration of statin and coronary collateral circulation.

The discriminatory performance of $\mathrm{N} / \mathrm{L}$ ratio with the grades of CCC was presented with an AUC value of 0.702 (95\% CI 0.619 - 0.785) which indicates the quality of moderate discrimination. The results of this study were not much different from previous studies of stable CAD populations with multivessel disease and chronic total coronary occlusion. Other studies have received similar quality of discriminatory performance with AUC value of $0.73,0.71,0.784$, and $0.74 .18,21,45,46$ In this study, the N/L cut-off point was 1.99. Other studies have obtained cutoff values of 2.55, 2.75, and 2.17. 18,21,45 This difference was based on various baseline leukocyte count, absolute neutrophil and absolute lymphocyte in each population (Caucasians versus Asian races). The subject of this study had higher leukocyte and neutrophils, and lower lymphocyte compared to other studies in Caucasians. This caused N/L cutoff value to be lower than other studies.

\section{Conclusion}

Higher neutrophil to lymphocyte ratio was useful in predicting poor coronary collateral circulation in stable coronary heart disease with multivessel disease. Neutrophil to lymphocyte ratio $>1.99$ was independently associated with impairment in coronary collateralization. This value had a sensitivity of $78.9 \%$ and specificity of $52 \%$.

\section{References}

1. Marzilli M, Merz CN, Boden WE, et al. 2012. Obstructive coronary atherosclerosis and ischemic heart disease: An elusive link! J Am CollCardiol 60:951.

2. Pepine CJ, Douglas PS. 2012. Rethinking stable ischemic heart disease: Is this the beginning of a new era? J Am CollCardiol 60:957.

3. Gloekler S, Seiler C. 2007. Natural bypasses can save lives. Circulation 116:340-341.

4. Seiler C. 2010. The human coronary collateral circulation. Eur J Clin Invest 40:465-476.

5. Popma JJ, Kinlay S, Bhatt DL. 2015. Coronary arteriography and intracoronary imaging. Chapter 20. In: Mann DL, Zipes DP, Libby P, Bonow RO, and Braunwald E. Braunwald's heart disease: a text book of cardiovascular medicine. 10th ed. Philadelphia: Elsevier Saunders. pp 392-424. 
6. Habib GB, Heibig J, Forman SA, et al. 1991. Influence of coronary collateral vessels on myocardial infarct size in humans: Results of phase I Thrombolysis In Myocardial Infarction (TIMI) Trial. Circulation 83:739746.

7. Berry C, Balachandran KP, L'Allier PL, Lesperance J, Bonan R, Oldroyd KG. 2007. Importance of collateral circulation in coronary heart disease. Eur Heart $J$ 28:278-291.

8. Verma S, Wang CH, Li SH, et al. 2002. A self-fulfilling prophecy: C-reactive protein attenuates nitric oxide production and inhibits angiogenesis. Circulation 106:913-919.

9. Bhat T, Teli S, Rijal J, Bhat H, Raza M, Khoueiry G, et al. 2013. Neutrophil to lymphocyte ratio and cardiovascular diseases: a review. Expert Rev CardiovascTher 11:55-9.

10. Sawant AC, Adhikari P, Narra SR, Srivatsa SS, Mills PK, Srivatsa SS. 2014. Neutrophil to lymphocyte ratio predicts short and long term mortality following revascularization therapy for ST elevation myocardial infarction. Cardiol J.

11. Darmawan. 2016. Peran Rasio Netrofil Limfosit Sebagai Prediktor Major Adverse Cardiac Events Tujuh Hari dalam Perawatan Pada Pasien Sindrom Koroner Akut. FK UI.

12. Horne BD, Anderson JL, John JM, et al. 2005. Which white blood cell subtypes predict increased cardiovascular risk? J Am CollCardiol 45: 1638-1643.

13. Oncel RC, Ucar M, Karakas MS, et al. 2015. Relation of Neutrophil-to-Lymphocyte Ratio With GRACE Risk Score to In-Hospital Cardiac Events in Patients With ST-Segment Elevated Myocardial Infarction. ClinApplThrombHemost, May; 21(4):383-8.

14. Huang G, Zhong XN, Zhong B, et al. 2009. Significance of white blood cell count and its subtypes in patients with acute coronary syndrome. Eur J Clin Invest 39:348-58.

15. Kirtane AJ, Bui A, Murphy SA, et al. 2004. Association of peripheral neutrophilia with adverse angiographic outcomes in ST-elevation myocardial infarction. Am J Cardiol93:532-536.

16. Hotchkiss RS, Karl IE. 2003. The pathophysiology and treatment of sepsis. N Engl J Med 348: 138-150.

17. Mor A, Luboshits G, Planer D, Keren G, George J. 2006. Altered status of CD4(+) CD25(+) regulatory T cells in patients with acute coronary syndromes. Eur Heart J 27:2530-7.

18. Kalkan ME, Sahin M, Kalkan AK, et al. 2014. The relationship between the neutrophil-lymphocyte ratio and the coronary collateral circulation in patients with chronic total occlusion. Perfusion 29(4):360-366.

19. Nacar AB, Erayman A, Kurt M, et al. 2015. The Relationship between Coronary Collateral Circulation and Neutrophil/Lymphocyte Ratio in Patients with Coronary Chronic Total Occlusion. Med PrincPract24:65-69.

20. Rentrop KP, Cohen M, Blanke H, Phillips RA. 1985. Changes in collateral channel filling immediately after coronary artery occlusion by an angioplasty balloon in human subjects. J Am Coll Cardiol 5:587-592.
21. Uysal OK, Turkoglu C, Sahin DY. 2015. The Relationship between Neutrophil-to-Lymphocyte Ratio and Coronary Collateral Circulation. Clinical and Applied Thrombosis/Hemostasis21(4):329-333.

22. Atsari, FA. NilaiIndeksSyokModifikasi, SkorTimi, danSkor Grace Sebagai Prediktor Kejadian Kardiovaskular Mayor Selama Masa Rawatan pada Pasien Infark Miokard Akut dengan Elevasi Segmen ST. FK USU

23. Koerselman J, de Jaegere PP, Verhaar MC, Grobbee DE, van der Graaf Y; SMART Study Group. 2007. Coronary collateral circulation: the effects of smoking and alcohol. Atherosclerosis. Mar;191(1):191-8.

24. Kadi, H, Ozyurt H Koksal C, Koc F, Celik A, Burucu T. 2012. The Relationship between High-Density Lipoprotein Cholesterol and Coronary Collateral Circulation in Patients With Coronary Artery Disease. J Investig Med 60: 808-812

25. Rossi F, Bertone C, Montanile F, et al. HDL cholesterol is a strong determinant of endothelial progenitor cells in hypercholesterolemic subjects. Microvasc Res 80:274Y279.

26. Sue I, Escargueil-Blane I, Troly M, et al. 1997. HDL and ApoA prevent cell death of endothelial cells induced by oxidized LDL. Arterioscler Thromb Vasc Biol 17:2158Y2166

27. Pohl T, Seiler C, Billinger M, et al. 2001. Frequency distribution of collateral flow and factors influencing collateral channel development. Functional collateral channel measurement in 450 patients with coronary artery disease. J Am CollCardiol 38:1872-1878

28. Piek JJ, van Liebergen RA, Koch KT, et al. 1997. Clinical, angiographic and hemodynamic predictors of recruitable collateral flow assessed during balloon angioplasty coronary occlusion. J Am CollCardiol 29:275-282.

29. Werner GS, Ferrari M, Betge S, et al. 2001. Collateral function in chronic total coronary occlusions is related to regional myocardial function and duration of occlusion. Circulation 104:2784-2790.

30. Meier P, Schirmer SH, Lansky AJ, Timmis A, Pitt A, Seiler C. 2013. The collateral circulation of the heart. BMC Medicine 11:143.

31. Folsom AR, Aleksic N, Catellier D, Juneja HS, Wu KK. 2002. C-reactive protein andincident coronary heart disease in the Atherosclerosis Risk InCommunities (ARIC) study. Am Heart J 144:233-238.

32. Folsom AR, Rosamond WD, Shahar E, et al. 1999. Prospective study of markers of hemostatic function with risk ofischemic stroke. The Atherosclerosis Risk in Communities (ARIC) Study Investigators. Circulation 100:736-742.

33. Lee S, Choe JW, Kim HK, Sung J. 2011. High-Sensitivity C-Reactive Protein and Cancer. J Epidemio 121(3):1618

34. Saito K, Kihara K. 2010. Role of C-reactive protein as a biomarker for renal cellcarcinoma. Expert Rev Anticancer Ther 10:1979-1989.

35. Pitsavos C, Tampourlou M, Panagiotakos DB, et al. 2007. Association Between Low-Grade Systemic Inflammation and Type 2 Diabetes Mellitus Among 
Men and Women from the ATTICA Study. Rev DiabetStud 4:98-104.

36. Nakanishi N, Sato M, Shirai K, Suzuki K, Tatara K. White blood cell count as a risk factor for hypertension; a study of Japanese male office workers. J Hypertens 2002, 20:851-857.

37. Marsland AL, McCaffery JM, Muldoon MF, Manuck SB. 2010. Systemic inflammation and the metabolic syndrome among middle-aged community volunteers. Metabolism 59:1801-1808

38. Drakopoulou M, Toutouzas K, Stefanadi E, et al. 2009. Association of inflammatory markers with angiographic severity and extent of coronary artery disease. Atherosclerosis 206:335-339.

39. Ateş AH, Canpolat U, Yorgun H, et al. 2011. Total white blood cell count is associated with the presence, severity and extent of coronary atherosclerosis detected by dual source multislice computed tomographic coronary angiography. Cardiol J 18:371377.

40. Sabatine MS, Morrow DA, Cannon CP, et al. 2002. Relationship between baseline white blood cell count and degree of coronary artery disease and mortality in patients with acute coronary syndromes: a TACTICSTIMI 18 (Treat Angina with Aggrastat and determine Cost of Therapy with an Invasive or Conservative Strategy thrombolysis in myocardial infarction 18 trial) substudy. J Am CollCardiol 40:1761-1768.

41. van der Hoeven NW, Teunissen PF, Werner GS, et al. 2013. Clinical parameters associated with collateral development in patients with chronic total coronary occlusion. Heart 99:1100-1105.

42. Seiler C, Pohl T, Billinger M, Meier B. 2003. Tumour necrosis factor alphaconcentration and collateral flow in patients with coronary artery diseaseand normal systolic left ventricular function. Heart 89:96-97.

43. Gulec S, Ozdemir AO, Maradit-Kremers H, et al. 2006. Elevated levels of C-reactive protein are associated with impaired coronary collateral development. Eur J Clin Invest 36:369 -375.

44. Chia S, Nagurney JT, Brown DF, Raffel OC, et al. 2009. Association of leukocyte and neutrophil counts with infarct size, left ventricular function and outcomes after percutaneous coronary intervention for STelevation myocardial infarction. Am J Cardiol 103: 333-7.

45. Akin F, Ayça B, Çelik Ö, Şahin C. 2015. Predictors of poor coronary collateral development in patients with stable coronary artery disease: Neutrophil-tolymphocyte ratio and platelets. Anatol J Cardiol 15:218-223.

46. Demir K, Avci A, Altunkeser BB, Yilmaz A, Keles F, Ersecgin A. 2014. The relation between neutrophil-to lymphocyte ratio and coronary chronic total occlusions. BMC Cardiovascular Disorders 14:130. 